\title{
TEACHERS’ PEDAGOGICAL BELIEF AND ITS REFLECTION ON THE PRACTICE IN TEACHING WRITING IN EFL TERTIARY CONTEXT IN BANGLADESH
}

\author{
Md. Eftekhar Uddin, Assistant Prof. \\ Department of English Language and Literature \\ International Islamic University Chittagong, Chittagong Bangladesh
}

\begin{abstract}
Writing is the most focused but the least developed English language skill among the learners in Bangladesh. At tertiary level the situation is not different. Surely, alternative approach(es) different from the current practices in teaching writing is/are the timely need to alter the poor standard in English writing of tertiary level students. Cognition or belief related literature suggests what teachers think and believe has a great impact on classroom practices. So, this study investigates teachers' pedagogical belief in teaching writing assuming it as a vital first step to bring innovations in teaching practices. A mixed-method study was carried out in this regard. 15 teachers from a private university responded to the questionnaire used for this study and two teachers from the same institution were interviewed. The results show a marked discrepancy between teacher belief and practice. Teachers' lack of orientation in different approaches to teaching writing and contextual constraints are, the study finds out, the major causes behind it. Despite the findings need further extensive research to be validated, the results in this study are definite pointers to the dire necessity of teacher education featuring pedagogical orientation on different approaches to teaching writing, techniques of more student engagement in writing process, ways to increase student motivation in writing and procedures of technology integration and using in teaching writing.
\end{abstract}

Keywords: Teacher belief, Teaching writing, Teacher education

\section{Introduction}

\section{Background to the study}

As an EFL (English as a Foreign Language) teacher in a private university in Bangladesh, I am always interested in carrying out an extensive 
research on teaching writing. My interest stems from the fact that writing is the most emphasized but the least developed skill among the students in my context. From my experience as a tertiary level teacher I have noticed in my context, mostly, in a teacher-centred classroom, developing writing is viewed as achieving grammatical accuracy, developing structural qualities, and gaining knowledge and ability to produce different genres of writing. Students being passive often play the role of information reproducers in a writing classroom. They hardly get opportunity to exercise their creative process of independent thinking and writing within the constraints of a classroom setting. As a result, outside the classroom in a real life, students often falter in showing confidence and capability in producing creative and independent writing. I think approach to teaching writing in my context needs a shift from the teacher-centred to the student-centred to develop autonomy and confidence among learners in writing.

Before any innovation or changes to work properly, it is essential to understand what beliefs the teachers in my context have about teaching writing as teachers are "active, thinking decision-makers who make instructional choices by drawing on complex, practically-oriented, personalised, and context sensitive networks of knowledge thoughts, and beliefs” (Borg, 2003, p. 81). Thus, teachers' thinking systems play a major role in their approaches to, and innovation in, everyday teaching. Therefore, I decided to conduct a study on the interrelation between teachers' belief and practice in teaching writing in my context so that I could recommend suggestions and changes in teaching writing keeping the findings of my study in mind.

The in-depth understanding of Bangladeshi context regarding the use and teaching of English language, with especial focus on writing instruction would definitely substantiate my study on the co-relation between teachers' belief and practice in teaching writing, so the next section throws light on it.

\section{English Language instruction in Bangladesh}

The history of Bangladesh and its language are closely entwined with each other. The people of Bangladesh sacrificed their lives in a movement to establish their mother tongue 'Bangla' as their national language in 1952. Ultimately, the movement culminated in the emergence of Bangladesh as an independent nation in 1971. During the pre-independent period, English played a dominant role in every sphere of life in this territory and functioned as the lingua franca. However, with the emergence of Bangladesh as a separate state and the proclamation of Bangla as the sole national language of it, the importance of English diminished and it lost its second language status and turned into a foreign language because of the nationalistic feelings associated with the first language. The visible consequence is poor standard 
in English language teaching and subsequent decrease in its roles and functions in the country.

Even, with English being a compulsory subject both in schools and in high schools, the non-use of English outside the classroom seems not to change the poor standard of English in Bangladesh. Hoque (1999) pertinently remarks- "Despite the considerable amount of time devoted to English instruction, the general proficiency and achievement of the majority of the students graduating from high schools is unsatisfactory and disproportionately low" (p.93). Similarly, English Language Teaching Task Force of 1976 set up by the Ministry of Education of Bangladesh (cited from Rahman 1999, p.15) found out that, "The English proficiency of students in class 9 was two years and in class 12 four years behind the level assumed in their textbooks."

In 2001, recognising the importance of communicative competence inside and outside the classroom, English textbooks were redesigned based on Communicative Language Teaching (CLT) approach replacing the earlier Grammar-Translation method (GTM). However, the new curriculum appeared not to bring desired results among students (see Chowdhury \& Ha, 2008; Hamid \& Baldauf, 2008; Hamid, Sussex, \& Khan, 2009). The main reason, as reported in the literature, is the lack of orientation regarding the new methodology among teachers who mostly learned English by means of GTM (Hasan \& Akhand, 2009). Besides, I think, the lack of environment outside the classroom to practice English is also a cause.

At the tertiary level, the situation, understandably, is not so dissimilar. Even, in private universities like my study context, with English being the medium of instruction, the proficiency level of English among students is very low. The lack of pedagogical knowledge among teachers on different approaches to teaching English and the lack of English environment outside the classroom are the main reasons behind such poor status in English in Bangladesh.

\section{Present situation of writing instruction in EFL classroom in Bangladesh}

As I mentioned earlier, writing is the most emphasized skill in English instruction in Bangladesh because students in different professional and academic exams are required to show their command over English through writing. Still, it is the least developed skill among students. Ahmed (1999) cites a concrete example of it from his study-

The best student in the class [made] as many as ten errors of article use (wrong article and no article where one is required). You can guess the number of errors made by her class mates who are a long way behind her. These students had read English for about 12 years before they came to university ... (p. 168). 
Writing in my study context is viewed mainly as developing grammatical and structural accuracy. Students in my context are not provided with the opportunity to develop skills independently or with others in collaboration within the constraints of a classroom to experience and practice the stages to become good writers. Hoque (1999) pertinently remarks-

. . . both teachers and students of English are mainly concerned about teaching and learning textbook contents, grammar rules, etc. through this traditional grammar-translation method-they are hardly involved in practical and participatory activities for teaching and learning language skills (p. 95) .

As a result, even with linguistic knowledge students often struggle to produce a cohesive piece of writing.

The discussion in this section reflects the poor standard of Bangladeshi students in English language especially in writing skill. So, teachers need to come with apt approaches, methods and techniques in teaching writing to alter the existing situation. And such innovations to work properly it is necessary to understand what teachers think and believe regarding their current practices in a classroom and about changes suggested or implemented. Accordingly, steps can be taken to shape up their thoughtprocess and this study is designed to find so.

\section{Research Question}

The research question I have framed for my study is as follows:

"What pedagogical beliefs do teachers have in a private university in Bangladesh that inform their approach to teaching writing in English?"

In other words, I would like to investigate in a Bangladeshi private university context what teachers believe about writing and how far these beliefs shape their practice in the writing classroom. Alternatively saying, I would like to investigate what teachers practice in the writing classroom and to what extent the practice reflects their belief and is based on pedagogy.

\section{Literature review}

This section presents the literature review on the two key concepts in my research topic: teachers' belief and teaching writing. These concepts and related studies are reviewed to inform the research methodology and the data analysis procedure I used for my study. The discussion here, will also form a base for the recommendations I am going to make for my research context.

\section{Teacher Belief}

The teaching profession can be seen as the juxtaposition of a teacher's individual and social values reflected in teaching and learning in a 
particular context. This perspective is quite similar to Borg's (2003) view of teachers as 'active, thinking decision-makers who make instructional choices by drawing on complex, practically-oriented, personalised, and contextsensitive networks of knowledge, thoughts and beliefs' (p.81). In short, teachers' thought process what I have termed in this study as 'teachers belief' plays an important role in any approaches teachers incorporate and any innovation they bring in their everyday teaching.

\section{Definition of 'Teacher Belief'}

Borg (2003) conceptualises teacher belief what he terms 'teacher cognition' as teachers' 'knowledge, theories, attitudes, images, assumptions, metaphors, conceptions, perspective about teaching, teachers, learning, students, subject matter, curricula, materials, instructional activities, and self' (p.81). Besides, over past decades there are so many cognate terms for teacher belief that have been utilised by researchers such as 'teacher knowledge' (Freeman, 2002), 'teachers' theories'(Borg, 1999), and teachers' 'personal theories'(James, 2001).

Pajares (1992) reviewed a literature of beliefs and reported that beliefs were defined in most studies as a 'conceptual tool'. He defined belief as an "individual's judgment of the truth or falsity of a proposition, a judgment that can only be inferred from a collective understanding of what human beings say, intend, and do" (p. 316). According to Aguirre and Speer (2000), current definitions of teacher beliefs found in the education literature focus on how teachers think about the nature of teaching and learning. In this context, beliefs are defined as "conceptions" (Thompson, 1992, p. 132), world views, and "mental models" that shape learning and teaching practices (Emest, 1989, p. 250).

\section{Formation of teacher belief and its impact}

Borg (2006) suggests a framework (see Figure 2.1) including four elements (Schooling, Professional Coursework, Contextual Factors, and Classroom Practice) that are instrumental in forming teacher belief. It shows that school experiences form the important base behind teachers' ideas about teaching and learning and these ideas have an impact in their professional life. Teachers' concepts about teaching and learning may be tailored and sharpened later by professional development training and through new pedagogical orientations. However, some contextual elements like syllabus and teaching culture may act as the catalyst behind the practices of the teachers which are not reflective of their underlying beliefs. Meanwhile, teachers' classroom experiences influence belief 'unconsciously and/or through conscious reflection' (Borg. 2006, p.283). Other researchers(Meijer, Verloop, \& Beijaard 1999 ) also come up with similar sort of conclusions 
that what teachers know, understand and believe is constructed as a result of classroom experience, interaction with students and professional training programs. Research (Andrew, 2003; Cuban, 1993; Freeman, 2002; Golombek, 1998; Pajares, 1992) also suggests that classroom behaviours of the teachers that influence students' learning are governed by teachers' beliefs about learning and teaching. Extensive experience of ${ }_{-}$May affect existing cognitions classrooms which defines early cognitions and shapes teachers' although especially when perceptions of initial training. unacknowledged, these may limit its impact.

4
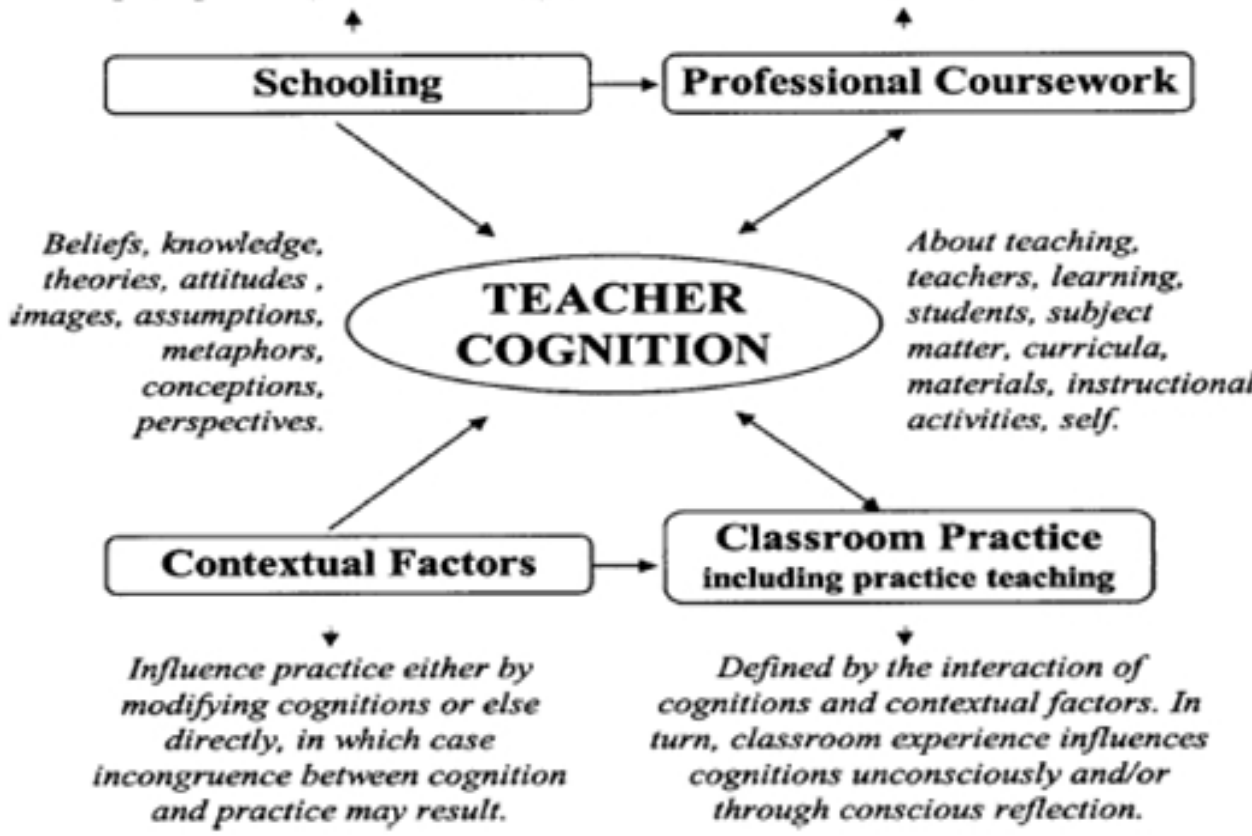

Figure 2.1.2 : Formation of teacher cognition (Borg, 2006, p.283)

The literature reviewed so far brings to light two notable points related to my study.

First, teacher belief is highly influential in shaping classroom practice, so, any process of innovation in teaching and learning for developing writing what I aim to achieve based on this research in my study context should start with an attempt to understand teachers' belief, opinion and views regarding it.

Second, teacher cognition can be shaped and tailored through professional development programs. So, before organising such programs, it is mandatory to understand what beliefs teachers hold regarding any innovation like technology integration. Otherwise, training programs might not be able to feature the areas the teachers need help most to implement any innovation effectively. 


\section{Teaching writing}

Teaching writing to EFL learners is one of the most challenging tasks for language teachers as it needs high competence in language and 'it takes considerable reflection and experience' to respond to student writing (Ferris, 2007, p.179). In absence of any professional development programs at tertiary level in my study context, teachers are likely to depend on their personal experiences as students, and on the understanding of their classroom situations through observing others or using own intuition to shape their approach to teaching writing. Therefore, it is essential to know what teachers understand and believe about writing instruction as it has an impact on their classroom behaviour and practices.

\section{Teachers' approaches to writing}

Writing is the most emphasized skill in my study context. Teachers in writing classrooms play a key role in helping students develop ideas and content, in providing models and different kinds of writings to follow, and in giving feedback through correcting grammatical mistakes and developing structures. All these efforts seem not to work as students in real life often falter in producing a piece of writing independently and creatively. So, relevant literature regarding approaches to teaching writing has been reviewed to understand what approach my participating teachers are following and to suggest what approach suits them best and how.

There are mainly four pedagogical approaches that form the base behind the practice in writing instruction in English: product approaches, process approaches, genre approaches, and process-genre approaches.

In product approach, teachers' focus is on the teaching linguistic features and 'logical construction and arrangement of discourse forms' (Silva, 1990, p.14) in writing. 'Product-based approaches see writing as mainly concerned with knowledge about the structure of language, and writing development as mainly the result of the imitation of input, in the form of texts provided by the teacher'(Badger \& White, 2000, p. 154). It seems this is a teacher centric approach concentrating on mainly linguistic and structural features of a language. This is the approach what teachers follow in my study context.

The process approach has non-linear discursive four stages: prewriting/planning; composing/drafting; revising; and editing (Badger \& White, 2000). Here the emphasis is on the student and his development as a writer, who like all other writers needs to follow the stages stated here to complete his writing and the role of a teacher is to facilitate the process. So, the approach helps students exercise independence and creativity in writing. However, Badger and white (2000, p. 154) argue that this approach fails to recognise the need of different processes for different types of writing. 
The genre approach emphasises that different social contexts require different genres of writing (Badger and White, 2000). So, the writing tasks are to be designed to prepare students to function in such different social contexts.

The process-genre approach is the amalgam of the three approaches while addressing the flaws of each. According to Badger and White (2000), process-genre approach recognises that,

'writing involves knowledge about language (as in product and genre approaches), knowledge of the context in which writing happens and especially the purpose for the writing (as in genre approaches), and skills in using language (as in process approaches) writing development happens by drawing out the learners' potential (as in process approaches) and by providing input to which the learners respond (as in product and genre approaches)' (p. 157-158).

In seeking the most suitable approach to writing, teachers need to understand contextual reality and pedagogical understanding on how to tailor each approach or all to fit into their context. Say, for example, to address the flaws in the product approach used in my study context, the possible alternative could be implementing the process approach to make students autonomous in writing. But the question is how far it is possible to exercise the stages of the process approach within the constraints of classroom setting in my research context, so, this approach needs an extended platform to be implemented, probably, through the process of technology integration. Prior to making all these decisions about the best approach in writing, it is mandatory for the teachers to understand the strength and the weakness of each approach so that they can decide what approach suits their context and how. Professional development programs could be arranged to provide pedagogical understanding to teachers on different approaches to writing. As Sengupta and Ziao (2002) remark such training programs can expand and modify teachers' belief about writing.

\section{Teaching context and writing instruction in English}

Researches (Pennington, Brock, Yue, 1996) have shown that practices in English writing classroom are shaped up by contextual influences. They report a gap between beliefs and classroom practices. They identified the following contextual constraints that have caused the gap:

- Students' level of English

- Expectation about teaching and writing

- Teachers' knowledge and perceptions about writing practices

- Time

- Examination and syllabus requirements 


\section{Methodology}

This section presents a description of the methodological approach I have undertaken for my study.

\section{Research settings and participants}

The research was carried out with EFL teachers and the teachers belong to the 'Department of English Language and Literature' of a topranked private university located in Chittagong, the port city of Bangladesh. I have been associated with this university and with the department as one of the EFL teachers almost from its very inception and this has influenced me to base my study here.

Participants who are my colleagues and close acquaintances are full time teachers in the department. All 15 colleagues of the department responded to the questionnaire designed for my study. Cluster sampling (Dornyei, 2003) has been followed to select them. My participating teachers, in Cohen et al.'s words (2007, p.104), do not 'represent the wider population' of tertiary teachers in Bangladesh, rather the results of this study are solely the views of a particular group which could be used as a base to carry out further research to make generalizable findings applicable to all the tertiary teachers in Bangladesh.

Besides, my two colleagues, one $(\mathrm{H})$ is an Associate Professor, male and also former Head of the department and the other (F) is a female Assistant Professor, afterwards have been interviewed. The participating teachers (H \&F) in this study do not, as Cohen, Manion, and Morrison (2007, p.104) put it, "represent the wider population" of tertiary teachers in the context they are working. However, their range of experience and expertise as teachers brought different dimensions to my research. The male colleague has been in the department from its very inception and playing an integral part in designing departmental curriculum and syllabus. Recently he obtained his $2^{\text {nd }}$ MA in ELT from the University of Essex. The female colleague has been the product of the department she has been working now, so, she has two dimensional experiences: one as a student and another as a teacher.

\section{Adopted research methodology for the study}

For the research on teacher cognition, the relevant literatures (Beijaard, van Driel, \&Verloop, 1999; Black \& Haliwell, 2000; Kagan, 1990; Meijer et al., 1999) suggest a wide range of methodologies and instruments such as journals, questionnaires, interviews, stimulated recalls, classroom observation, short-answer tests, practical arguments and conversation etc. to understand teachers' thought process about teaching and learning. Pertinently, Barcelos (2003) and Borg (2003) remark that a mixture of research approaches on teacher cognition may reveal multi-dimensions of 
teachers' thought process towards particular behaviour, actions or concepts what one particular method may unable to produce. So, a mixed- method approach combining quantitative and qualitative (Dornyei, 2003) is useful to 'generate deeper and broader insight, to develop important knowledge claims that respect a wider range of interests and perspectives' (Greene et al.,1997, p.7).

So, I employed a mixed method approach for my teacher belief study regarding teaching writing.

\section{Data collection instrument}

As mentioned earlier, the instruments I used for my data collection was a questionnaire inspired from Suwannasom (2010) for quantitative data and interviews for qualitative data.

Brown (2001, p.6) defines questionnaires as "any written instruments that present respondents with a series of questions or statements to which they are to react either by writing out their answers or selecting from among existing answers". A questionnaire involves less “(a) researcher time, (b) researcher effort, and (c) financial resources” (Dornyei, 2003, p.9) to process huge amount of data in comparison to other methods. These advantages prompted me to embark on this instrument.

The method I chose to generate qualitative data for my research is interviewing. Interviewing can take a number of forms but the one I used is termed 'non-standardized interviews online' (Mann et al, 2000, p.75). These types of less structured interviews are conducted with individuals or with groups by email or by chatting using real time software with or without video interface. According to Creswell (2003) and Fontana and Frey (2000), this type of interview is conversational and offers maximum flexibility to ask spontaneous questions depending on individual differences and situational changes. This style of interview suited the purpose of my research as I needed to get access to what is inside a person's mind. Nevertheless, it does not mean that conversational interviews in this study were unfocussed. The purpose of the study was maintained by means of interview prompts (Appendix A).

Moreover, my interview was conducted in Bangla, the native language of the participants. I think my participants were more relaxed in voicing their inner thoughts in Bangla than in English.

\section{Development of the questionnaire}

The questionnaire (see Appendix B) was developed based on the literature review on second language writing (Hyland, 2003). 
In questionnaire participants were provided a number of statements to select from in accordance with their belief about students' and teachers' behaviour in the writing classrooms.

In A items were designed to understand teacher cognition about students' behaviour in the writing classrooms. The aim was to find out what my participating teachers believed students should develop or be engaged in. I mean whether teachers prefer students developing grammatical accuracy or developing a relationship with others through writing and whether teachers wanted students to be engaged in a collaborative task or in an individual task.

In B I used two categories of verbs in the statements to understand teacher cognition about teachers' behaviour and the role in the writing classrooms. The first category includes the verbs like 'help', 'provide', and 'give' and the second includes 'encourage', 'facilitate' and 'create'. These categories were meant to indicate two contrasting roles of a teacher in a writing classroom: the first category implies teacher as a transmitter of knowledge and the second, teacher as a facilitator. The given tables would exemplify the point further.

\begin{tabular}{|c|c|c|}
\hline \multicolumn{3}{|c|}{ First Category } \\
\hline \multirow{2}{*}{ Teachers } & Statement & Interpretation of behaviour \\
& $\begin{array}{c}\text { help students develop ideas. } \\
\text { provide models of texts. } \\
\text { give feedback on accuracy of language. }\end{array}$ & $\begin{array}{c}\text { Teacher centred writing classroom. } \\
\text { Teacher as a knowledge transmitter. }\end{array}$ \\
\hline
\end{tabular}

\begin{tabular}{|c|c|c|}
\hline \multicolumn{2}{|c|}{ Second Category } \\
\hline \multirow{3}{*}{ Statement } & $\begin{array}{c}\text { Interpretation } \\
\text { of behaviour }\end{array}$ \\
\hline Teachers & $\begin{array}{c}\text { Student } \\
\text { a local newspaper. } \\
\text { create a favourable environment } \\
\text { for students to write a lot. } \\
\text { facilitate collaborative tasks. } \\
\text { classroom. }\end{array}$ \\
\hline
\end{tabular}

\section{Data collection procedures}

Before the start of the data collection phase, I sent emails to all my possible participants informing them about my intended research topic with some general ideas related to it along with a consent letter to be signed by them as an acknowledgment to their willingness to participate. After that, I emailed the questionnaires in a word document file to those participants who returned the consent letters with signatures. Though I thought initially of sending an on-line questionnaire, I discarded the idea assuming that participants might feel difficulty in downloading it and responding to it because of the infrequent net connection in my study context. In addition, I 
made contact with the participants over phone several times to reinsure their participation, to request to make responses to my questionnaire quickly, and to clarify any difficulties in understanding and in responding any parts of the questionnaire. And interviews I conducted on line with Skype, a computer tool for conversation with video interface, in separate sessions with two participants. Each session lasted around 30 minutes.

In terms of data collection, I made audio recordings of the interviews with the computer software 'Pamela for Skype' and decided not to take notes, in order not to distract from the discussion.

\section{Data analysis procedures}

First of all, I organised and prepared the data, collected through the questionnaire and interviews for analysis. The data were then sorted into two types: quantitative data in the form of responses of the participants to different items in the questionnaire and qualitative data in the form of descriptive responses of the interviewed participants.

Throughout the data analysis procedure, as an indispensable part of my study context, I used my own experience and familiarity to interpret the responses from my participating teachers.

\section{Quantitative data analysis}

The respondents to my questionnaire were only 15 , so I did not use SPSS or any of the computer software to analyse the answers to the questionnaire items. Instead, I counted manually the number of responses in each part and put in a sheet. Afterwards, I analysed them to find out any noticeable pattern in relation to my research questions and in line with the rationale behind designing each item in a questionnaire what I discussed in the preceding section (3.4).

\section{Qualitative Data analysis}

Since the qualitative data in my study were interview accounts, they were subjected to content which requires coding and categorising the data. In this regard, Cohen et al. (2007) suggest that content analysis means coding, creating meaningful categories, comparing and making connections between data, and drawing conclusions based on theory from the text.

I started the data analysis by listening to the recorded interviews and transcribing them into the text form. For obtaining a general sense of the data, I read through all the transcriptions, took notes and wrote general thoughts about the data. The data were reviewed and reorganised for the preliminary coding. Then, I clustered related data together and labelled each cluster according to its characteristic. The emerged categories from the interview were then scrutinized to separate the important ones in relation to 
my research topic. The segregated categories were afterwards translated in English, though in a paraphrase form.

Throughout the analysis, participants are referred to as $\mathrm{F}$ and $\mathrm{H}$ to ensure their anonymity. For the sake of continuing the flow of interpretation I have used $\mathrm{F}$ and $\mathrm{H}$ in brackets so that it is understood which participant provided the data.

The major categories emerged from my qualitative data are as follows:

- Participants' belief about language learning

- Participants' belief about writing

- The interrelationship between teachers' belief and practice in classrooms

I have analysed my interview data using headings like the above ones.

\section{Analysis and interpretation \\ Quantitative data analysis}

Teacher cognition about writing

In the questionnaire participating teachers were asked to select items concerning on what behaviour they expected from students and what role teachers should play in writing classrooms.

\section{Behaviour of the students in the writing classroom}

The results of the questionnaire revealed that most of the participating teachers expected students to produce grammatically correct sentence, to be able to write different kinds of writing like reports, letters and essays etc., and to be able to focus structures in the model text. Moreover, majority of the participants in my study preferred students to work individually rather than collaboratively. On the other hand, only a few participants believed students should build relationship through writing and be aware of readers' expectation while writing. It suggests that almost all the teachers in my study hardly thought of writing as a social tool for students to communicate with others. Rather, they were more concerned with students' development of grammatical correctness, structural accuracy, and understanding of different types of discourses.

\section{Teachers' role in writing classroom}

Looking at the top five items selected by my participating teachers, it is assumed that teachers in my study context would like to play an active role in writing classes. They preferred to provide students different types of texts as models to follow, help students in generating ideas and content of the writing, decide and provide exercises for students to complete according to the level of their proficiency. In addition, they would also like to give 
corrective feedback to students' writing. Overall, it seems writing class is mostly teacher centred in my study context. My assumption gets validated when I see the survey results. It shows that only a few participants preferred teachers playing the role of a facilitator in encouraging students to do a collaborative task, or in creating a favourable environment for students to do a lot of writing and to exchange writing with others. Teachers seem not to favour the idea of students' playing active roles in writing classes or they think that their students need scaffolding from their teachers because of their inferior capability.

However, in the survey it is observed that all the participating teachers would like to encourage their students to write for a student magazine or a local newspaper. It can be interpreted as the reflection of their belief in writing as a social tool. But I would like to disagree with this view as I know from my affiliation with my study context the reason behind their preference to this item in the questionnaire. Once, one of the participating teachers thought of starting a project where students had to send letters to a local newspaper. He felt that if letters got published it would boost up the confidence of the students. The project was a success and afterwards other teachers simply followed the trend. So, teachers' preference to encourage students to write for local newspapers was not influenced by or based on sound pedagogical understanding of learning and teaching a language. If it were a pedagogy driven decision, teachers would have also preferred other activities where writing is regarded as a social tool.

\section{Qualitative Data Analysis}

\section{Participants' belief about language learning}

Both interviewees believe that language is learned in a natural environment. Referring to her experience F remarks 'students learn a language mostly through listening. As a student when I was admitted to this department I listened to the tutors which helped me a lot to learn. Tutors only played the role of a facilitator. The same principle applies to every student.' Similarly $\mathrm{H}$ opines 'students learn a language through communicative activities in a natural environment'.

\section{Participants' belief about writing}

My participants believe that 'writing is a process' $(\mathrm{H})$ and 'writers follow several stages to write: gathering idea, planning, revising, drafting etc. and students also need to follow these stages to write.' (F) 


\section{The interrelationship between teachers' belief and practice in classrooms}

Both the interviewees readily admit that teachers are unable to practice in classrooms what they believe. $\mathrm{H}$ remarks pertinently 'our perception and practice stand opposite to each other. We believe in communicative teaching but students prefer rote learning'. He exemplifies his stand referring to his research work. He finds that similar kinds of topics feature in the writing exams by turn. He thinks such tradition encourages rote learning as exams directly control classroom practice. The participants provided the following reasons for the discrepancy between belief and practice in their context.

- Large classroom $(\mathrm{H})$

- Exam oriented culture (H \& F)

- Demands of syllabus completion on time(H \& F)

- Low-level students $(\mathrm{H})$

- Time constraints (H)

When $\mathrm{H}$ was asked what changes he made as the Head of the department to reflect his belief, he says 'he introduced some features (brainstorming, planning etc.) of process approach in the writing syllabuses'. However, $\mathrm{F}$ does not feel positive about these features. She believes these features students can learn automatically. She reports that she talks most of the time in the writing classroom to make students understand what brainstorming is, how to make plans etc. leaving little space for students to practice writing. She even wishes to change the syllabus to make it more practice based focusing on creative writing.

When $\mathrm{F}$ was asked what she does in the classroom, she provides a list of her activities in the classroom. She gives a topic, helps students generate ideas about it, sometimes provides a sample, then lets students write on it, and finally she corrects the students' writing at the sentence and word level. The things she does inside the classroom reflects her belief in the product approach at the application level, though at the theory level she earlier spoke in favour of the process approach to writing.

Both of the interviewees report that the present practices in the writing classroom may not reflect their belief but are helpful in bringing marked improvements among students.

\section{Beliefs about in-class and out of class activities}

The stages of the process approach require students to be engaged in out of class activities as the stages could not be followed within the classroom. Since the participants believe in the process approach I asked them how they would value in and out of class activities. 
$\mathrm{H}$ is sceptical about the effectiveness of out of class activities. He gives prime importance to the classroom because he feels inside the classroom his students will get peer and teacher support what they will not get outside the classroom. When $\mathrm{H}$ was reminded of his UK academic experience where out of class activities were more, he pointed out that UK culture could not be replicated in his context because of the difference of academic tradition and academic skill among students.

$\mathrm{F}$, however, supports more engagement of the students in out of class activities even through reduction of number of classes.

\section{Beliefs about technology integration in writing classes}

Technology is another avenue through which the process approach to writing could be facilitated. Both the interviewees believe in the affordances of technology but $\mathrm{H}$ is doubtful whether technology integration is feasible in his context. He remarks that 'students and teachers sometimes do not get the electricity let alone the internet facility.

$\mathrm{F}$, on the other hand, is interested in technology integration. She reports that through social networking sites students have already improved without formal instructions.

\section{Summary of the findings}

Regarding belief about teaching and developing writing, teachers reported that they emphasised students on developing basic writing skills such as the ability to write sentences with grammatical correctness, the ability to focus on structures in a given model, and the ability to understand and practise different genres. Teachers also reported they preferred to play a central role in scaffolding the students to develop these skills in writing classrooms. It implies that these teachers concentrated more on developing students' earlier stages in writing and preparing them instead of letting them prepare and develop with skills necessary in their tertiary context. The idea of developing students as writers with ability to communicate and socialise with others in the authentic real-life world seemed not to be present among teachers.

The findings suggest that my participating teachers need orientation regarding different approaches to teaching writing other than what they follow along with practical demonstration on how each approach functions. The knowledge would help them understand the benefits of empowering students in writing classrooms and make them realise that writing is mainly a skill for social interaction in the real world.

From interview, however, my research study suggests that teachers have sound pedagogical beliefs about writing though they are unable to translate them into practice and reality due to contextual reality and lack of 
orientation in different approaches to teaching writing especially at the application level.

\section{Limitations of the study}

As mentioned earlier, the respondents of the study was limited, only 15 and the method used for this study was only a questionnaire instead of a mixed-method approach. So, the findings of this study do not have the required authenticity to be generalizable.

In my study through the questionnaire the findings reflect mere opinions of teachers regarding their beliefs in teaching writing. But the study does not reflect what teachers do inside the classroom based on their beliefs. So, further extensive research through classroom observation is required to validate the outcomes of this study.

In the study it seemed a couple of participants were going through the motion and following others in responding the questionnaire. So, these findings need further probe to get validated.

\section{Recommendation}

\section{Pedagogical orientation on approaches to teaching writing:}

My study manifests inconsistency in writing teachers' espoused belief and teaching practice. For example, participating teachers remarked that they preferred process approach to teaching writing, but there was little evidence in their practice. They either do not know what process approach entails or they fail to come up with ideas to materialize the stages of process approach in their context.

Another alternative interpretation of our findings is that the teachers are merely going through the motion reporting what they think they believe without having deep understanding and convictions on what they. This suggests that substantial professional development is needed to help teachers in understanding different approaches and providing them with the competencies to transform their pedagogical practices. According to Muijs and Reynolds (2002), belief systems alter through practical experience. If teachers do not experience practical demonstration on how each approach to teaching writing shapes in a classroom, they tend to teach the way they have been taught. That's why Calderhead and Robson (1991) and Kagan (1992) warn that mere lecturing on theories and approaches have negligible effect in changing teachers' pedagogical beliefs and practices.

Besides such experiences, Stofflett and Stoddart (1994) claim that teachers need opportunities to contrast these new experiences with their existing teaching and learning activities. They suggest it helps teachers to critically reflect on what they do, what they should do, and what can be done in their context. Eventually, it may become instrumental in restructuring of 
their existing beliefs and eventually adopt a new practice that is consistent with their pedagogical beliefs.

\section{Technology use for writing instruction to ensure engagements inside and outside the classroom}

A variety of technological tools may be used for EFL writing instruction. For example, Meyer \& Rose (2000) suggests a classroom website as a suitable means to generate motivation among students to write for authentic readers which ultimately boost up their confidence and performance in their writing. According to Stout \& Murray (2008) class blogs afford "students to collaboratively write blog entries" (p.756). Since these entries are for real audience, I in agreement with Seitzinger (2006) feel that blogs definitely enhance writing skill, promote self-reflection on one's own writing, develop critical thinking and make learners active in learning.

E-mail has been called "the mother of all Internet applications" (Warschauer, Shetzer, and Meloni, 2000, p.3). Since the evolution and revolution of networking world through internet, computers can opportune foreign language (FL) learners with more than drills: "they can be a medium of real communication in the target language, including composing and exchanging messages with other students in the classroom or around the world" (Oxford, 1990, p.79). Besides, writing projects with email, a familiar tool in my study context, provide students opportunity to communicate with native speakers and enable them to have authentic communicative language learning experience (Gonglewski et al., 2001).

Recently, researchers (Cress \& Kimmerle, 2008; Guzdial et al., 2001; Yukawa, 2006) suggest using Wiki for creating an interactive, authentic and collaborative writing environment for students. Wiki means a number of interlinked webpages in which users can leave his mark through reading, adding, organising and editing the content (Schwartz et al., 2004). Wikis can be used to facilitate students working in a project with opportunities for collaborative writing. And in such collaboration, creativity is promoted, knowledge is shared and socialisation takes place and all these facilitate learning (Cress \& Kimmerle, 2008; Guzdial et al., 2001; Yukawa, 2006)

\section{Reforming assessment system}

Lim and Chai (2008) opines, and I agree, assessment system is the 'final frontier' against teachers adopting any innovations in their practice. Teachers are catalyst in furthering students' career and course-end exam results are very important in this regard. Naturally, teachers are keen on engaging students in activities that ensure good grades for them no matter how contrary they are to their beliefs. In my context, de-emphasising learning outcomes in terms of grades may be necessary. If that is not possible 
teachers need to come up with ideas to put equal weight on both learning outcomes and final grades in writing class.

\section{Recommendations for future research}

My recommendation for further research has several phases.

1st phase: The findings of my present study should be validated by further research with instruments like classroom observation and interviews.

2nd phase: Using the validated findings and recommendations here as principles, professional training program should be organised. Later, a further investigation should be made to understand the impact of training on classroom behaviours.

$3^{\text {rd }}$ phase: To make the findings generalizable, the above three phases should be replicated with larger samples in other private and public universities as well.

\section{Conclusion}

Now I realise that any innovation I am willing to introduce into my context needs to be tailored according to contextual reality. Based on my study, I feel teachers in my context require more application level understanding of the different approaches to writing to minimise the gap between their belief and practice in the classroom.

I also feel that the beliefs of the teachers in my context need to be extended and enhanced through training programs and these programs should practically demonstrate how different approaches to writing function at the application level, how technology can be brought into the classroom practice keeping socio-cultural setting into consideration and how out of class activities could be linked in a balanced way with in- class activities. Overall, this study can be used as a stepping stone for further research on teachers' belief and its relation to teaching writing.

\section{References:}

Aguirre, J., \& Speer, N. M. (2000). Examining the relationship between beliefs and goals in teacher practice. Journal of Mathematical Behaviour, 18(3), 327-356.

Ahmed, S. (1999). The Problem of Teaching English Grammar to BengaliSpeaking Students. In Collected Papers (1999). (pp.167-172). Dhaka: The British Council and the NCTB.

Andrews, S. (2003). Just like instant noodles: L2 teachers and their beliefs about grammar pedagogy. Teachers and Teaching, 9 (4).351-375.

Badger, R., \& White, B. (2000). A process genre approach to teaching writing. ELT Journal, 54, 153-160. 
Barcelos, A. (2003). Researching beliefs about SLA: A critical review. In P. Kalaja \& A. Barcelos (Eds.). Beliefs about SLA: New research approaches (pp. 7-33). Dordrecht: Kluwer.

Beijaard, D., van Driel, J., \& Verloop, N. (1999). Evaluation of story-line methodology in research on teachers' practical knowledge. Studies in Educational Evaluation, 25, 47-62.

Blake, A. L.,\& Halliwell, G.(2000). Accessing practical knowledge: How? Why? Teaching and Teacher Education, 16, 103-115.

Brown, J. D. (2001). Using surveys in language programs. Cambridge, UK: Cambridge University Press.

Borg, S. (2006). Teacher cognition and language education: Research and practice. London: Continuum.

Borg, S. (2003). Teacher cognition in language teaching: A review of research on what language teacher think, know, believe, and do. Language Teaching, 36 (2), 81-109.

Borg, S. (1999). Teachers' theories in grammar teaching. ELT Journal, 53 (3). 157-67.

Calderhead, J. \& Robson, M. (1991). Images of teaching: student teachers' early conceptions of classroom practice. Teaching and Teacher Education, 7, $1-8$.

Chowdhury, R., \& Ha, P.L. (2008). Reflecting on western TESOL training and communicative language teaching: Bangladeshi teachers' voices. Asia Pacific Journal of Education, 28(3), 305-316.

Cohen, L., Manion, L., \& Morrison, K. (2007). Research Methods in Education (5th ed.). London: Routledge Falmer.

Creswell, J. W. (2003). Research design: Qualitative, quantitative and mixed method approaches. Thousand Oaks, CA: Sage.

Cress, U., \& Kimmerle, J. (2008) A systemic and cognitive view on collaborative knowledge building with wikis. International Journal of Computer-Supported Collaborative Learning, 3, 105-122.

Cuban, L. (1993) Computer meets classroom: Classroom wins. Teachers College Record, 95 (2), 185-210.

Dornyei, Z. (2003). Questionnaires in Second Language Research. Mawah, New Jersey: Lawrence Erlbaum Associates, Publishers.

Emest, P. (1989). The impact of beliefs on the teaching of mathematics. In P. Emest (Ed.), Mathematics teaching: The state of the art (pp. 249-254). London: Falmer Press.

Ferris, D. R. (2007). Preparing teachers to respond to student writing. Journal of Second Language Writing, 16(3), 165-193.

Fontana, A., \& Frey, J. H. (2000). The interview: From structured questions to negotiated text. In N. K. Denzin \& Y. S. Lincoln (Eds.), Handbook of qualitative research (pp. 645-672) Thousand Oaks, CA: Sage. 
Freeman, D. (2002). The hidden side of the work: Teacher knowledge and learning to teach. Language Teaching, 35, 1-13.

Golombek, P. (1998). A study of language teachers' personal practical knowledge. TESOL Quarterly, 32 (3), 447-464.

Gonglewski, M., Meloni, C., \& Brant, J. (2001). Using email in foreign language teaching: Rationale and suggestions. The Internet TESL Journal, 7(3). Retrieved January, 2011, from http://iteslj.org/Techniques/MeloniEmail.html

Green, J. C., \& Caracelli, V. J. (Eds.) (1997). Advances in mixed-method evaluation: The challenges and benefits of integrating diverse paradigms. San Francisco: Jossey-Bass.

Guskey, T. R. (1986). Staff development and the process of teacher change. Educational Researcher, 15(5), 5-12.

Guzdial, M., Rick, J., \&Kehoe, C. M. (2001). Beyond adoption to invention: Teacher-created collaborative activities in higher education. Journal of the Learning Sciences, 10(3). 265-279.

Hamid, M.O., \& Baldauf, R.B. (2008). Will CLT bail out the bogged down ELT in Bangladesh? English Today, 24(3), 16-24.

Hamid, M.O., Sussex, R., \& Khan, A. (2009). Private tutoring in English for secondary school students in Bangladesh. TESOL Quarterly, 43(2), 281-308. Hasan, K., \& Akhand, M.M. (2009). Challenges \& suitability of TESL at the college level in Bangladeshi context. Journal of the Nepalese English Language Teachers Association (NELTA), 14(1-2). Retrieved from http://www.libjournals5.lib.sfu.ca:8092/index.php/NELTA/article/view/3090 $/ 2708$

Hoque, S. (1999). ELT Issues in Bangladesh: An Overview. In Collected Papers, (pp. 93- 100). Dhaka: The British Council and the NCTB

Hyland, K. (2003) second language writing. Cambridge, NY: Cambridge. University Press.

James, P. (2001). Teacher in action. Cambridge: Cambridge University Press.

Kagan, D. M. (1990). Ways of evaluating teacher cognition: Inferences concerning the Goldilocks principle. Review of Educational Research, 60, 419-469.

Kagan, D. M. (1992). Implications of research on teacher belief. Educational Psychologist, 27, 1,65-90.

Lim, C. P. \& Chai, C. S. (2008) Teachers' pedagogical beliefs and their planning and conduct of computer-mediated classroom lessons. British Journal of Educational Technology, 39 (5), 807-828

Mann, C. and Stewart, F. (2000). Internet Communication and Qualitative Research: A Handbook for Researching Online. London,:Sage. 
Meijer, P. C., Verloop, N., \& Beijerd, D. (1999). Exploring language teachers' practical knowledge about teaching reading comprehension. Teaching and Teacher Education, 15, 59-84.

Meyer, A., \& Rose, D. H. (2000). Learning to read in a computer age. Retrieved 22 July 2011 from http://www.cast.org/library/books/ltr/chapter5.html

Muijs, D. \& Reynolds, D. (2002). Teachers' beliefs and behaviours: what really matters? Journal of Classroom Interaction, 37, 2, 3-15.

Oxford, R. (1990). Language learning strategies. New York: Newbury House.

Pennington, M. C., Brock, M.N., \& Yue, F. (1996). Explaining Hong Kong students' response to process writing: An exploration of causes and outcomes. Journal of Second Language writing,, 5(3), 227-252.

Rahman, H. (1999).English Language Teaching in Bangladesh: Didactics on the pragmatics of a Foreign Language Teaching Policy. In Hunter, T. (ed) National and Regional Issues in Language Teaching: International Perspective (ELTIP Conference Proceeding). Dhaka: The British Council. (pp. 5-32).

Schwartz, L., Clark, S., Cossarin, M. \&Rudloph, J. (2004). Technical evaluation report 6.27. Educational Wikis: Features and selection criteria. The International Review of Research in Open and Distance Learning, 5(1). 1492-3831.

Seitzinger, J. (2006). Be constructive: Blogs, podcasts, and wikis as constructivist learning tools. Learning Solutions e-Magazine. Retrieved July 2011from http://www.elearningguild.com/pdf/2/073106DES.pdf

Sengupta, S., \& Ziao, M. K. (2002). The contextual reshaping of beliefs about L2 writing: Three teachers practical process of theory construction. Teaching English as a Second or Foreign Language- EJ, 6, A-1.

Stout, M., \& Murray, A. (2008). Blogging to learn English: A report on two blog projects in Japan. In K. Bradford Watts, T. Muller, \& M. Swanson (Eds.), JALT 2007 Conference Proceedings. Tokyo: JALT.

Warschauer, M., Shetzer, H. \& Meloni, C. (2000). Internet for English teaching. Alexandria. VA: TESOL Publications.

Silva, T (1990). Second language composition instruction: Developments, issues, and directions in ESL.

Stofflett, R. T. \& Stoddart, T. (1994). The ability to understand and use conceptual change pedagogy as a function of prior content learning experience. Journal of Research in Science Teaching, 31, 1, 31-51.

Suwannasom, T. (2010) Teacher cognition about technology mediated EFL instruction in Thai tertiary context (Doctoral Dissertation, Massey University, 2010). 
Thompson, A. G. (1992). Teachers" beliefs and conceptions: A synthesis of research. In D. A. Grouws (Ed.), Handbook of research on mathematics teaching and learning (pp. 127-146). New York: Macmillan.

Yukawa, J. (2006). Co-reflection in online learning: Collaborative critical thinking as narrative. International Journal of Computer-Supported Collaborative Learning, 1.203-228.

\author{
Appendix A \\ (Interview prompts) \\ Interviewees will be asked about following points: \\ - Views on language learning \\ - Why writing important in your context \\ - Stages of writing/ how you write/ opinions about how students write \\ - Practices in the writing classes \\ - Reasons behind their practices \\ - Responses to their practices \\ - Thoughts about out of class activities \\ - Thoughts about technology
}

\title{
Appendix B \\ Questionnaire
}

Beliefs about EFL writing Instruction

A. Directions: Please read the following statements about student behaviours and put a check $(\sqrt{ })$ to choose

5 items which you think are the most important features for the Bangladeshi tertiary EFL writing instruction.

\begin{tabular}{|l|l|}
\hline 1. Students are able to write grammatically correct sentences. & \\
\hline 2. Students learn how to revise their own drafts as well as to give feedback on the others'. & \\
\hline 3. Students have opportunities to exchange ideas about their writing. & \\
\hline 4. Students are aware of the readers' expectation when they write & \\
\hline 5. Students develop relationship with others through written texts. & \\
\hline 6. Students usually work independently to complete their drafts. & \\
\hline 7. Students usually work collaboratively to complete their drafts. & \\
\hline 8. Students develop different kinds of writing (e.g. letters, reports, and essays). & \\
\hline 9. Students study focused structures in model texts before write their own. & \\
\hline
\end{tabular}

B. Directions: Please read the following statements about teacher behaviours and put a check $(\sqrt{ })$ to

choose 5 items which you think are the most important features for the

Bangladeshi tertiary EFL writing instruction.

\begin{tabular}{|l|l|}
\hline 10. Teachers help students to develop the content and ideas of the writing. & \\
\hline 11. Teachers encourage students to write for a student magazine or a local newspaper. & \\
\hline 12. Teachers provide writing exercises for students according to their proficiency. & \\
\hline 13. Teachers facilitate group collaborative writing tasks. & \\
\hline 14. Teachers give corrective feedback about the students' language in their drafts. & \\
\hline 15. Teachers provide students different types of texts as models of good writing. & \\
\hline 16. Teachers create a positive environment for students to do a lot of writing & \\
\hline 17. Teachers encourage students to write in response to questions or feedbacks. & \\
\hline 18. Teachers encourage students to exchange their writing with pen pals or key pals. &
\end{tabular}

